\title{
Power, hegemony, and social reality in Gramsci and Searle
}

\section{Matthew Rachar}

To cite this article: Matthew Rachar (2016) Power, hegemony, and social reality in Gramsci and Searle, Journal of Political Power, 9:2, 227-247, DOI: 10.1080/2158379X.2016.1191222

To link to this article: http://dx.doi.org/10.1080/2158379X.2016.1191222

\section{册 Published online: 10 Jun 2016.}

Submit your article to this journal $\pi$

Џ Article views: 7

Q View related articles $\widetilde{ }$

View Crossmark data $\nearrow$ 


\title{
Power, hegemony, and social reality in Gramsci and Searle
}

\author{
Matthew Rachar* \\ Department of Philosophy, Graduate Center, CUNY, New York, NY, USA
}

\begin{abstract}
This paper reconstructs Gramsci's account of social objects in light of recent developments in analytic social ontology. It combines elements of Gramsci's account with that of John Searle, and argues that when taken together their theories constitute a robust account of social reality and a nuanced view of the relation between social reality and power. Searle provides a detailed analysis of the creation of social entities at the level of the agent, while Gramsci, by employing his concepts of hegemony and domination, is able to provide an analysis of the differential ability of societal subgroups to construct the social world.
\end{abstract}

Keywords: social ontology; hegemony; Gramsci; Searle

\section{Introduction}

Antonio Gramsci develops a detailed theory of social reality based on the intuition that not all objects have their properties because of their material composition. Despite emerging from a divergent tradition, Gramsci shares this motivating intuition about the nature of social entities with several modern theorists of social ontology. The central task of this paper is to reconstruct Gramsci's account with the modern debate in mind, and develop the novel suggestions contained therein. I make two specific claims. First, working within the Marxist tradition leads Gramsci to give a superior account of the role of power in the origination and nature of social reality. More specifically, his account of hegemony and civil society provides us with a framework to analyze the difference between specific powers that are created by social reality and the wider sense of power on which social reality depends, as well as the differential power of certain groups to create social reality. Second, these insights may be combined with the concepts and distinctions developed in recent analytic social ontology in order to develop a powerful social theory.

I begin by sketching the concerns and questions addressed by philosophers such as John Searle, Raimo Tuomela, Frank Hindriks, and Amie Thomasson, and then considering the specific account of social entities given by John Searle. In order to argue for the claims made above, I first place Gramsci's work within the Marxist tradition to show why he holds that a full account of social objects is necessary. I then detail Gramsci's account of social reality and trace the connections between this account and his concepts of hegemony, political power, and civil society. Finally, I consider the extent to which Gramsci's account provides a satisfactory answer to the questions raised in the first section, and compare his account to that of Searle. I argue that Gramsci's focus on the political and historical nature of

*Email: mrachar@gradcenter.cuny.edu 
social objects leads him to develop two important aspects of an analysis of social reality. First, he claims that we need to give an 'ideological critique' of the belief systems that inform our collective acceptance of social objects, and second, that we need to adopt the 'genealogical perspective' toward particular social objects in order to understand their function and place in society. However, because Gramsci's account takes place at the societal level, it is underspecified with regard to the construction of social entities by particular agents. It is therefore only when these two ideas are combined with the analysis of Searle that we get a comprehensive picture of the creation of social reality that also allows for the proper recognition of the dependence of social objects on social and political power.

\section{Social ontology: three questions}

As the first claim of this paper is that Gramsci provides an account of social reality in line with the modern debate, the first task is to clarify the nature of that debate. In its current form, there are three central questions that motivate the study of social ontology in the analytic tradition. These questions provide the metric by which we can evaluate the theories of Gramsci and Searle. ${ }^{1}$ The first is metaphysical: how can human intentionality create 'real' facts and objects? The existence of objects like money, banks, laws, and corporations, and facts like 'Canada is a parliamentary democracy' seem to challenge the common sense notion that believing something to be the case cannot make it so, as they depend on the intentional states of individuals for whatever 'reality' they have. Social entities are the products of human agreement or acceptance which in turn rely upon human beliefs and intentions. In this way then, they differ from natural objects, which exist independently of any process of human intentionality. This difference causes many to question the genuineness of such entities. Searle states this concern nicely by pointing out that in the creation of social entities we have a sense that 'there is an element of magic, a conjuring trick, a sleight of hand' and that:

In our toughest metaphysical moods we want to ask ... are these bits of paper really money? Is this piece of land really somebody's private property? ... Surely when you get down to brass tacks, these are not real facts. $(1995$, p. 45)

Any adequate theory of social ontology must provide a palliative for this kind of concern, a story which explains how social entities may both be the product of human intentionality and parts of objective reality without being completely reducible to their material composition.

The second question is epistemological: if social entities depend on collective acceptance and intentional states such as belief, how can we come to know new things about them? It appears that in order for these things to exist, we need to have some beliefs about them, and because their particular role is determined by our beliefs and intentions, it is unclear how we could discover previously unknown facts about them. Nonetheless, it is clear that the social sciences do exactly that. This concern has two parts. First, many of the entities that depend upon some form of acceptance still remain opaque in many ways, take, for example, predictions about the behavior of the US Supreme Court. Second, many seemingly unintended, and perhaps in some cases completely unknown, higher level social facts arise from individual actions within accepted institutions. Patterns of police behavior, 
conviction rates, and sentencing disparities resulting from the actions of individuals within the social institutions that depend on human intentionality may reveal that the particular system contains racial bias without any form of collective acceptance about that particular consequence. One important desideratum of a theory of social ontology is that it is able to confront these questions, and provide some insight into the logical structure of the objects studied by the social sciences, which in turn allows for a more thorough examination of the methods and understanding of the results of social scientific investigations.

The third question is also dependent on our answer to the first, and concerns the role of power and coercion in social reality: if we are responsible for creating the social world through our intentional actions, how is it that when we are faced with social entities they appear to be independent of our will, and at times even exhibit a strong power over us? This question has two subparts. The first concerns our encounter with the social entities. Social facts have control over us because they shape and guide our choices and actions. This may both take the form of either a limiting of our horizon of possibilities or an enabling of new possibilities. It is impossible to become president without independent social facts, just as it is possible to restrict certain groups of people from participating in social institutions such as marriage. There is, however, a second, much less discussed, sense in which social entities have coercive power. The ability to create and institute social entities is hierarchical. Not all subgroups in a society are equally endowed with the ability to construct the social world in which they live. For these subgroups then, the social objects they encounter will not only be coercive in the first sense, but also in the sense that the functions ascribed to these objects will appear foreign, or worse, counter to their interests. It is on this point that the account provided by Gramsci far exceeds the account developed by Searle, and adds something vital to the modern debate, an analysis of the relations of power involved in the construction of the social world.

\section{Searle's account of social reality}

One of the most prominent modern attempts to answer these questions has been put forward by Searle $(1995,2010)$. According to Searle, the construction of social reality depends upon one central operation, 'Status Function Declarations'. Searle states that 'All of human institutional reality ... is created in its initial existence and maintained in its continued existence by a single, logico-linguistic operation ... a Status Function Declaration' (2010, p. 201). A 'status function declaration' is an act, although not necessary a speech act, that involves linguistic representations that take the following form: 'We make it the case by Declaration that the Y Status Function exists in context C' $(2010$, p. 99). The complexity of human institutional reality is explainable in these simple terms because these rules can apply to any subject matter and can be recursively applied such that the outcomes of earlier applications are the inputs for new declarations. The combination of broad subject matter and our ability to apply the operation repeatedly to layer status functions on top of one another creates the intricate interlocking structures of institutional facts familiar from actual human societies.

Some further discussion of these concepts is required to explicate this basic idea. First, declarations denote a particular kind of speech act for Searle that makes something the case simply by representing it as such. Searle states that declarations 
'change the world by declaring that a state of affairs exists and thus bringing that state of affairs into existence' (2010, p. 12). A standard example is the leader of a meeting saying, 'This meeting is adjourned'. We use this basic form of linguistic representation to impose 'status functions' on entities. Status functions are distinguished from 'agentive functions' on the grounds that 'status functions' are functions which cannot be performed solely on the basis of their physical characteristics, but rather require collective acceptance and recognition of that function (2010, p. 59). Roughly, a hammer functions as a hammer for an agent because of a certain set of physical features which allow it to serve the agent's purpose, while money could take a variety of forms and still function as money, but in any of these forms it requires that other agents also take it as money.

The important point for us is that the creation of an institutional fact depends on collective acceptance. Searle argues that for institutional facts to exist 'there must be collective acceptance or recognition' of the standing declaration or the ad hoc utterance $(2010$, p. 8). To avoid concerns that this type of acceptance implies approval, endorsement, or explicit agreement in all cases, Searle suggests that there is a range of attitudes that are sufficient by going on to say that 'Acceptance ... goes all the way from enthusiastic endorsement to grudging acknowledgement' (2010, p. 8). Thus, simply 'going along with it' designates the type of relation necessary and sufficient for the creation of an institutional fact.

By accepting a status function we create a set of deontic powers, which are powers expressible in terms of deontological notions such as obligations, rights, entitlements, and so on. Searle adds this to the logical form of status function declarations as follows:

We (or I) make it the case by declaration that a $\mathrm{Y}$ status function exists in $\mathrm{C}$ and in so doing we (or I) create a relation $\mathrm{R}$ between $\mathrm{Y}$ and a certain person or persons $\mathrm{S}$, such that in virtue of SRY, S has the power to perform acts (of type) A. (2010, pp. 101-102)

Putting this account together, status function declarations create a system of power relations which exist only because we collectively represent them as existing. For Searle, this is the fundamental idea of social ontology. Having the title to a house, for example, gives the owner certain powers to sell it, inhabit it and perhaps rent it out, depending on certain contextual factors. Further, other people accrue certain restrictions on their power, thus they may in certain cases be charged with trespassing if they enter the house uninvited.

Searle then offers a more comprehensive account of power. He claims that the notion of power is that of a capacity or ability, specifically of an agent, A, to get a subject, $\mathrm{S}$, to do $\mathrm{X}$ regardless of whether $\mathrm{S}$ initially wants to do $\mathrm{X}$ or not. Searle argues for two constraints on more detailed analyses of power. The first is based on the idea that the exercise of power 'is always an intentional act' (2010, p. 148), and that 'the concept of power is logically tied to the concept of the intentional exercise of power' $(2010$, p. 151). This means that in order to analyze power relations we need to specify the intentional content of a specific exercise of power. He calls this the 'intentionality constraint'. He then claims that 'any satisfactory discussion of power ... should be able to say, who exactly has power over exactly whom to get them to do exactly what' (2010, p. 152). He labels this the 'exactness 
constraint'. According to Searle, analyses of power that do not meet these constraints are not focused enough to be of value (2010, pp. 151-152).

Despite the limiting nature of these constraints, Searle wants to offer an account of the claim that society can exercise power over its members, and that social pressure can be a form of power. In order to do this, he introduces the idea of 'background/network' power, which is 'not codified, is seldom explicit, and may even be largely unconscious' (2010, p. 155). It takes the form of social pressure that dictates our everyday choices. The idea is that:

there is a set of Background presuppositions, attitudes, dispositions, capacities, and practices of any community that set normative constraints on the members of that community in such a way that violations of those constraints are subject to the negative imposition of sanctions by any member of the community. (2010, p. 160)

The upshot of this view is that even background power can be most reasonably explained in terms of individual members exercising power by imposing sanctions on other individuals for specific violations of implicit societal norms. Thus, Searle claims, we can analyze this claim about societal power in terms that satisfy the intentionality and exactness conditions.

Finally, Searle turns to political power. He holds that 'All political power is a matter of status functions, and for that reason all political power is deontic power' (2010, p. 164). This may strike some as strange, because it seems that there is something different about the power exercised by political bodies when compared to the power exercised by social institutions. In order to respond to this, Searle presents a specific view of government. He argues that governments have two special features: a monopoly on organized violence, and control of a territory. Consequently, governments take a primary role in the competing system of status functions and are the paradigm of public activity because they control the nature of social institutions. It is therefore 'the ultimate institutional structure' (2010, p. 161). We can see, however, that there is a tension in this view. Status functions rely on collective acceptance, which suggests that political power 'comes from below' (2010, p. 165), while a monopoly on organized violence implies coercion based on the threat of force. If the system of status functions associated with political power 'can continue to function only if there is a permanent threat of violence in the form of the military and the police' (2010, p. 163), as Searle admits, it seems to undermine the claims of collective acceptance, and further to undermine the claim that because political power relies on collective acceptance it 'differs from military power, police power, and the brute physical power that the strong have over the weak' (2010, p. 164). Searle recognizes this 'paradox', but does little to answer it (2010, p. 163). We will return to these claims in order to evaluate them after the presentation of Gramsci's account.

\section{Gramsci's account of social reality ${ }^{2}$}

\subsection{Historical background}

Gramsci develops an account of social objects that aims to solve many of these same issues, and he does so in response to a current of Marxist thought that was influential at the time. Because Gramsci's starting position, theoretical interests, and conceptual framework are foreign to the developers of the questions laid out in the 
first section and the account considered in the second section, we will need to briefly situate Gramsci's thought in order to show how he came to recognize these questions as important and how the questions themselves confront similar phenomena.

Aiming for a purely 'scientific socialism', many Marxists of the time removed any trace of 'subjective' or 'voluntaristic' elements from consideration in a serious theory of society. There are several examples of this line of thought in the 1920s, such as Kautsky in Germany and Plekhanov in Russia (Femia, 1981, pp. 66-67, Salamini, 1981, pp. 3-5). One theorist generally working within this tradition was Nikolai Bukharin. Partially, because it was the book to which Gramsci had access, Gramsci focuses his general critique of the 'vulgar materialism' of the orthodox Marxism of his time on Bukharin's Popular Manual. ${ }^{3}$

Under Bukharin's account, all existence is strictly material, and all mental activities are reducible to their physiological bases. Human subjectivity is denied any causal efficacy. As Bukharin states, 'Society and its evolution are as much subject to natural law as is everything else in the universe' (1969, p. 46). The basic idea of this view is that human behavior, social action, and ultimately the totality of society, in other words the objects normally considered to be the domain of the social sciences, can be studied and explained completely in the language of the physical sciences.

Gramsci's aim in attacking Bukharin was to restore a role for conscious, creative human activity in the study of society and in Marxist thought. He holds that 'Man does not enter into relations with nature just by being himself part of nature, but actively, by means of work and technique. Furthermore these relations are not mechanical. They are active and conscious' (cited Femia, 1981, p. 70). This consideration of the role of human subjective activity in the 'reality of the external world' leads Gramsci to question the thesis of economic determinism, the conception of the base and superstructure, and the common understanding of the aims and objects of the 'science' of 'historical materialism' (hereafter HM). It is here that Gramsci formulates his version of the problem of social ontology, which, as we will see, concerns what we would now call the questions of ontological creativity, epistemological opacity, and coercion.

\subsection{The reality of the external world: material basis and superstructure}

Bukharin presents a specific thesis that only a strict materialism is compatible with the 'reality of the external world'. Gramsci's account of social reality begins with his attack on this thesis (Salice, 2009, p. 367). He charges that Bukharin's discussion is 'badly framed and mostly pointless' (2007, p. 364; Q8, §215), ${ }^{4}$ because it is not the reality of the external world itself that needs to be analyzed by HM, but the popular belief in this thesis. Gramsci provides such an analysis. He claims that this common belief has a religious origin, regardless of the religious leanings of the people who currently adopt it. He states:

Since people have believed for centuries that god created the world before he created man and that man found the world already made and catalogued, defined once and for all, this belief has become a 'common sense' fact, even in those cases where religious feeling has been dulled. (2007, p. 365; Q8, §25) 
The interesting part of this claim for our purposes is that it explains one set of common 'everyday' beliefs by another set of common religious beliefs, and not with reference to the material bases of production. This indicates Gramsci's desire to break with the orthodox Marxist theses about the base and superstructure, which he then makes explicit:

Idealist theories constitute the greatest effort at intellectual and moral reform that has ever been made ... This is related to the question of how and to what degree the concept of superstructures of historical materialism is in fact a realization of idealism and of its assertion that the reality of the world is a construction of the spirit. (2007, p. 365; Q8, §215)

This quote reveals Gramsci's motivation for developing a social ontology. He is concerned with giving an account of the superstructures of society, namely social institutions, and ultimately what we take to be social reality, in terms of their construction by human subjectivity, and not purely in terms of their determination by the material bases of production. He states: 'it is not the economic structure that directly determines political action, but rather the interpretation given to it and to the so-called laws that govern its development' (cited Fontana, 2006, p. 42). In other words, Gramsci takes the reality of the superstructures to demand an explanation that includes the ontological creativity of human intentionality.

The last note from this section introduces another important theme in Gramsci's writing, the relationship between HM and the natural sciences. ${ }^{5}$ Gramsci states, 'The place of the natural or exact sciences within the framework of historical materialism. This is the most interesting and urgent question that needs to be resolved' (2007, p. 365; Q8, §215). The reason this question has such meaning for Gramsci is twofold. First, because the theories of natural science are theories, they are a type of superstructure, and because HM is the science of superstructures, the theories of natural science are objects of study for HM. Second, because HM understands itself as a science, although with a particular object of study, its relationship and methodological differences to the natural sciences must be explained.

Gramsci and Bukharin agree that HM is a science; Bukharin's mistake is to take this science to be continuous with the physical sciences (Salamini, 1981, p. 31). Gramsci states that:

To think that one can advance the progress of a work of scientific research by applying to it a standard method, chosen because it has given good results in another field of research to which it was naturally suited, is a strange delusion which has little to do with science. (1971, p. 439; Q11, §15)

For Gramsci, HM is its own science, with its own methods. Further, sciences can be separated according to their objects of study, and HM corresponds to a particular kind of object. Gramsci forcefully states his rejection of the metaphysical assumptions of the scientific Marxists as follows:

It is evident that, for the philosophy of praxis, 'matter' should be understood neither in the meaning that it has acquired in the natural sciences ... Matter as such [as developed by the natural sciences] is therefore not our concern [in the study of social phenomena]. (cited Femia, 1981, p. 72) 
However, as we have not yet explained what 'matter' is for HM, it still seems as if we have a paradox for HM. If the external world is objectively real and many of the objects of study of HM are in the external world, how can the existence of its objects of study be dependent on thought?

\subsection{Historical materialism}

This leads us to the question at the heart of Gramsci's social ontology: what is the nature of the objects of study for HM? To begin answering this question, let us turn to the following quote: "What does "objective" mean? Does it not mean "humanly objective" and therefore also humanly "subjective"?' (2007, p. 337; Q8, $\S 177)$. Here, Gramsci is somewhat unclear about the senses of objective and subjective he is employing. However, in another passage Gramsci states 'man knows objectively insofar as knowledge is real for all humankind historically unified in a cultural unitary system' (cited Salice, 2009, p. 368). In response to these two quotes, I offer the following interpretation of Gramsci. ${ }^{6}$ In 'humanly objective', 'objective' is a synonym for 'shared by the entirety of humanity' and is therefore a predicate that attaches to a proposition. If a proposition is 'shared by humanity', it is epistemically objective. Think, for example, of the proposition that 'Barack Obama is the president of the United States'. The negation of this predicate for a proposition that is not 'shared by humanity' is 'epistemically subjective'. Think, for example, of the proposition that 'Chocolate ice cream is better than strawberry ice cream'. In the second sense seen in 'humanly subjective', 'objective' is a predicate that applies to an object. Things like mountains and rivers exist independently of any subject, and can therefore be called 'objective' in this sense. The negation of this predicate applies to objects that depend for their existence on human intentionality, such as money, borders, and presidencies, and are therefore 'humanly subjective'.

From this passage, however, it is not clear that this interpretation of Gramsci's claim about the meanings of objective and subjective matches Gramsci's ideas. Elsewhere, he states that 'In vulgar materialist philosophy, the concept of "objective" appears to mean an objectivity that transcends man and can be known even apart from man - this is just a banal form of mysticism and nebulous abstraction' (2007, p. 338; Q8, §177). It appears here then Gramsci has gone too far in his rejection of materialism, and has fallen into an equally vulgar form of idealism, because this statement may lead us to the conclusion that nothing exists outside of humankind. We can divide Gramsci's thought here into two potential theses:

Thesis (1): If the entirety of humanity is convinced of the existence of an object X, then $\mathrm{X}$ exists in the ontologically subjective sense.

Thesis (2): If the entirety of humanity is convinced of the existence of an object X, then $\mathrm{X}$ exists in the ontologically objective sense.

In the following, I argue that (1) represents the foundation of Gramsci's social ontology. The epistemologically objective determines the ontologically subjective. In other words, certain propositions that are 'shared by humanity' (epistemically objective) bring entities into existence that are dependent on human intentionality 
(ontologically subjective). If, however, Gramsci is arguing for (2), his theory faces several problems. Because (2) grounds the objective existence of certain entities in human subjectivity it represents an untenable idealism. What is worse, it leaves open the possibility that the objective existence of the entities studied by the natural sciences is grounded in human subjectivity. Therefore, in order for Gramsci to have a coherent theory of social objects, he must defend (1).

We can determine which thesis Gramsci has in mind by attempting to answer the following two questions based on the two theses: (i) which objects exist only in relation to human intentionality? That is, what is the domain of the 'ontologically subjective'? And (ii) do any objects that are not ontologically subjective exist for Gramsci? That is, does Gramsci accept the category of 'ontologically objective'?

In order to answer the first question, we may turn to a passage in which Gramsci addresses an example of Bertrand Russell concerning the relation of East and West (Salice, 2009, p. 368). Russell makes the following claim:

The part of the earth's surface where Edinburgh stands would be North of the part where London stands even if there were no human beings to know about North and South and even if there were no minds at all in the universe. (1967, p. 56)

Russell is here attempting to defend the claim that predicates refer to universals that have an 'asubjective' existence.

In his response to this example, Gramsci denies that East and West refer to asubjective universals because the existence and structure of these entities is dependent on human intentionality. He states that 'East and West are arbitrary and conventional, that is historical, constructions, since outside of real history every point is East and West at the same time' (1971, p. 447; Q11, §20). On the other hand, Gramsci also holds that they are objectively real. He argues that East and West 'do not cease to be "objectively real" even though analysis shows them to be no more than a conventional, that is "historico-cultural" construction' (1971, p. 447; Q11, §20). The reason that they remain 'objectively real' is that their existence is accepted by a large and consistent group of people. Departing sharply from Russell's original concern, he points out that:

these terms have crystallised ... from the point of view of the European cultured classes who, as a result of their world-wide hegemony, have caused them to be accepted everywhere. Japan is the Far East not only for Europe but also perhaps for the American from California, and even for the Japanese himself, who through English political culture, may then call Egypt the Near East. (1971, p. 447; Q11, §20)

Thus, we see that for Gramsci certain objects are created by the beliefs and intentions of individuals or groups, and these objects are part of objective reality, giving us our answer to Question (1): some objects, namely 'historical-cultural constructions', are created by human intentionality and exist only in relation to it. Further, Gramsci recognizes the causal importance of these designations, and the role that they play in intentional action. He states that 'These references are real; they correspond to real facts, they allow one to travel by land and sea, to arrive where one has decided to arrive' (1971, pp. 447-448; Q11, §20).

It is important to note that for our purposes we do not need to accept Gramsci's rejection of universals or his specific rejection of East and West as universals (Salice, 2009, p. 368). His antirealism with respect to universals is irrelevant to his 
thesis that East and West have historical origins, conventional importance, and culturally dependent meanings, and therefore his thesis that they are social objects. If he is right that East and West are not universals, his thesis is certainly stronger because it means that they are fully social objects that exist purely on the basis of human intentionality. If they are universals, he may still defend the weaker thesis that there are universals that gain a new social dimension when they come into contact with human intentionality. As we will see, Gramsci will defend the idea that both are possible for different objects. In other words, some social objects are generated from natural objects coming into contact with human intentionality, while other social objects are created purely by human intentionality (Salice, 2009, p. 368).

From this passage we can also see the beginnings of Gramsci's most original contribution to the study of social ontology. It is not actually on the basis of the beliefs and intentions of the 'entirety of humanity' that East and West become social objects, but rather on the hegemony of the 'European cultured classes'. That is, the dominant social classes are able to impose the existence of social objects as a result of their position in a system of power relations. Further, these results are widely applicable. It is not simply geographical relations, but all social relations such as property, rights, and duties that have this structure.

For HM then, the objects of study are neither material in the sense of natural sciences, nor in the sense of the material metaphysics of the 'vulgar materialists', but rather are 'historicized' objects. Things become 'historicized' for Gramsci when they come into contact with human intentionality (Salice, 2009, p. 368, Fontana, 2012, pp. 128-129). For example, when someone produces a machine, it has a particular material base which can be studied by the natural sciences, but it is also a social object because it is dependent on human intentions for its creation, and because it enters into social relations of property and economic production. This second sense is the focus of HM. Even natural objects can become historical. For example, electricity existed purely as a natural entity until it became a productive entity in society, and entered into social relations. Only then did it become an object of study for HM. Gramsci states:

Historical materialism takes the physical properties of matter into account, of course, but only insofar as they become an 'economic factor' of production. The issue, then, is not matter as such but how it is socially and historically organized for production, as a human relation. $(1996$, p. $164 ;$ Q4, §25)

We now have an answer to the second question as well. Material entities such as electricity exist independently of human intentionality, but HM does not need to concern itself with them. As long as they have no role in human relations, it is the wrong disciplinary task. HM deals with 'historical objects', or in other words, with social objects. This is what gives it 'scientific autonomy' and characterizes its relation to the natural sciences (1996, p. 165; Q4, §25).

\subsection{Social objects}

Let us now take a closer look at Gramsci's account of these social objects. For Gramsci, all social objects have a function, and this function is dependent upon 'the way of living, thinking and acting of the ruling class' (2012, p. 126; Q14, §67). 
He recognizes that this implies that when ruling classes change, the social objects that depend on them go out of existence. In order to avoid this consequence, Gramsci discusses the 'rationality' of the function. He states that every social object is rational insofar as it has a 'useful function', but this does not mean that social objects "become "irrational" because the dominant social class has been stripped of its power and its strength of influence' (2012, p. 126; Q14, §67). While the functions are dependent on the ruling classes for their creation, they may also be transformed by succeeding cultures, and rationally developed to serve current interests. So, how do we discover whether a given function is rational? We do so by investigating the 'history' of the object, relation, or practice. Only through the study of history can we learn why a particular social object was created, what function it had, and whether it is continuing to fulfill that function.

This means that Gramsci's basic definition of a social object involves the application of a function at a particular time and relative to a particular social group, which includes both the ruling class and the ruled. This definition allows the function, and therefore, the nature of the social object, to change from one time to another and from one group to another. It also allows the nature of the object to remain the same over time and different groups, as long as it maintains the same function, which in turn can be either rational or irrational at different points and for different groups. Finally, there are both material and immaterial social entities. Material entities are things like machines and electricity, while immaterial entities are relations, rights, duties, and practices.

\subsection{Background ideology}

Gramsci also offers an original account of the types of mental attitudes on which these functions depend (Fontana, 2006, p. 43). He does this in order to show how social objects become 'crystallized' or how natural objects become 'historicized', and to show how they appear 'natural' or unchangeable when we encounter them. As we saw, Gramsci holds that the functions of social objects depend on the intentional attitudes of the ruling class. He argues that these attitudes can be collected together into belief systems, which can display more or less coherence and consciousness, where coherence refers to a lack of inconsistent beliefs and consciousness refers to the awareness of a belief system that it is a particular belief system that is shared by a social group. For example, common sense demonstrates the minimum of coherence and consciousness, while the natural sciences demonstrate the most.

Belief systems can take an abstract or a historical form. A particular system is abstract when it remains only the rational construct of a single individual. It is historical when it is able to propagate itself, and gain acceptance from a wider group of people. Only a belief system that is a system shared by a social group can create social objects. Gramsci's aim in his writings is for HM to take on this historical form. The social group with the hegemonic position in society is able to apply their belief system in order to determine the existence of social objects, and these social objects, because they exert some control over us, are vital to our behavior. For example, churches, prayer, and mass exist because the Christian religion became 'historicized'. Just as important, the practices of praying and going to church on Sunday equally depend on this historicization and the existence of the corresponding social objects. To take another example closer to Gramsci's main target, 
financial markets, stocks, bonds, and banks exist because the capitalist ideology became 'historicized', just as practices such as investing, taking out a loan, and starting a savings account do.

\subsection{Power, hegemony, and civil society}

This still leaves open two questions: what does it mean exactly for a belief system to become historicized, and how does this happen? It is here that Gramsci introduces his concept of hegemony, and his account of power relations in society. Gramsci distinguishes between two forms of the supremacy of a social group can take (Femia, 1981, p. 24): (1) leadership or consensus, and (2) rule or enforcement. Roughly, this is meant to represent a distinction between 'force' for (2), which manifests itself in the external rewards or punishments attached to specific behaviors, and 'consent' ${ }^{8}$ for (1), which manifests itself in the 'internal control' brought about by a society accepting a common understanding of social reality. Hegemony is the supremacy attained by 'consent' rather than 'force' (Fontana, 2006, pp. 27-29). Further, this distinction is meant roughly to correspond with the distinction between the state and civil society. In general, the state implements the coercive machinery for the exercise of 'force', while civil society is the battleground for 'consent'. Hegemony is thus primarily obtained through the institutions of civil society (Femia, 1981, p. 24).

These distinctions, however, are meant analytically and Gramsci does not claim that hegemony is purely advanced in civil society (Fontana, 2006, pp. 32-33). In order to better understand the process of 'historicization', we must analyze Gramsci's account of power relations to see how these elements interact. Gramsci argues for a tripartite view of social power. The first part is economic power. Stemming from the relations of production of society, social groups are differentiated as a result of a convergence of interests. Then, because the products of society are distributed unevenly across social groups, the groups that receive an inordinate share of the social product are granted material power over the less-privileged to further influence the relations of production. The second is political power, which is dependent upon the consistency and coherence of the belief systems of the groups formed by the relations of production. This is because groups that have coherent belief systems, of which they are conscious, are better able to act in unison to demand political power. This ability is also partly dependent on the degree of economic power possessed by the group in question. The development of the consciousness of these groups goes as follows: (a) the economic-primitive moment, in which people bind together in order to realize a single economic goal; (b) economic solidarity, in which the people in the groups realize that they have the same economic goals and the social groups become solidary groups; (c) the political moment, in which a social group recognizes that their own ideology can and must be shared with other social groups in order to achieve their collective goals (Salice, 2009, p. 368).

These power relations illuminate Gramsci's distinction between domination and leadership, in that they show how the adoption of a particular belief system functions in a state. A social group can lead by 'consensus' on the basis of their social hegemony without also being dominant in the military or police sense. Hegemony may then be understood as a type of 'voluntary submission' by one group to another as a result of their acceptance of the belief system of the leading group, in 
that the acceptance of a particular belief system by the non-hegemonic group is often not recognized to be the result of imbalanced power relations and therefore appears voluntary (Fontana, 2006, p. 31). Domination, in turn, is the enforcement of certain rules through military or police violence. This leaves us with three potential power combinations: (1) A group $\mathrm{X}$ can lead (by consensus), but not be dominant over a group Y; (2) A group X can be dominant, but not lead a group $\mathrm{Y}$ (dictatorship); and (3) A group $\mathrm{X}$ can be dominant and lead a group Y (parliamentary democracy).

Gramsci also gives an account of the process by which the acceptance of a belief system takes place, which, as it is a question of hegemony, largely takes place in civil society. Gramsci defines civil society according to the ideological superstructure, namely all the institutions, organizations and associations that create and diffuse modes of thought, such as journalists, schools, universities, and in our times, lobby groups, think tanks, and so on (Fontana, 2006, pp. 35-37). This distinction is meant to allow for significant interrelation between civil society and the state. The state, once it has achieved political power and is able to externally influence behavior through reward and punishment, also uses civil society to attempt to attain social 'consent'. Gramsci states that 'the State, when it wants to initiate an unpopular action or policy, creates in advance a suitable, or appropriate, public opinion; that is, it organizes and centralizes certain elements of society' (cited Femia, 1981, p. 27). However, the central idea of Gramsci's account is that the struggle for hegemony itself happens in civil society, and this may occur before political power is present, making it a major instrument for achieving political power (Femia, 1981, p. 54). Thus, we can see that there is a dynamic relation between civil society and political power. On the one hand, hegemony may arise from pre-existing social institutions, while on the other, political power may exercise itself in these institutions in order to further cement its hegemonic position.

\subsection{Gramsci's social ontology}

For our purposes, we may draw the following conclusions about Gramsci's social ontology. Social objects depend on the belief systems of particular social groups at particular times, and collective acceptance by a society. This acceptance is only possible when the belief system of a social group becomes 'historicized', that is when the belief system of a social group becomes accepted by a majority of people in the society, and this often requires the social group to achieve a hegemonic position in civil society. When all of these conditions are satisfied, the group is able to influence the nature of social reality. The central insight of this approach is that social reality is always based on power and interests. If we follow Gramsci and take hegemony to be 'the most important face of power' (Femia, 1981, p. 31), this account places power and coercion at the center, and develops a novel view of the political dimension of social reality.

\section{Answers to the three central questions}

Gramsci's political interests and position as a communist and revolutionary lead him to develop a specific political strategy. In order to do this, he recognizes that he needs an account of social reality and its construction. It does not, however, lead him to analyze the logical structure of this construction or its specific instantiations. 
Because many of Gramsci's claims are underspecified in this regard, they are compatible with several aspects of Searle's account. Nonetheless, the first aim of this section is to show that with some modification Gramsci provides an account which answers the central questions of social ontology considered here. Additionally, because Gramsci's project has a specific normative goal, he introduces several novel aspects to an analysis of social reality that are missing from Searle and much of the modern debate, specifically a 'genealogical perspective' and a thorough account of 'background ideology'. The second aim of this section is then to show how these aspects of Gramsci's thought may influence an account of social ontology, especially with regard to the role of power in social reality. When these two accounts are combined, we have a comprehensive theory of social reality that encompasses the construction of specific entities, the logical structure of these entities, their ideological nature, the genealogy of their functions, and the larger power relations that condition their existence.

\subsection{Metaphysical question}

With respect to the metaphysical question, the main point of agreement between Gramsci and the modern theorists is that social entities are dependent on human intentionality. There is a strong similarity between the concern Searle expresses about the 'magical' nature of social facts and the position put forward by Bukharin and the other 'vulgar materialists', in that they both question the 'reality' of social entities. Against this reduction to material foundations, both Searle and Gramsci argue that certain social entities exist and have causal powers over and above their material composition, and further, that this existence is dependent upon collective acceptance and is relativized to particular contexts, which in Gramsci are further specified to be particular groups and times.

Gramsci's account focuses on the acceptance at the level of the set of beliefs or ideology of a particular group with respect to social objects, while Searle focuses on the acceptance of particular standing or ad hoc declarations as they relate to social facts. There is nothing in Gramsci's account that does not permit this type of specific analysis. ${ }^{9}$ Because Gramsci's account remains general, in that it focuses on the belief systems of social groups rather than specific moments of implementation, we are free to interpret the specific instances of the institution of a social object in a variety of ways. We may then adopt Searle's claims about the structure and importance of declarations for specific social entities. ${ }^{10}$ By shifting the focus to the belief systems that allow for these declarations, however, we may develop a more nuanced account of how this acceptance comes about. There may be a standing declaration to the effect that the person that receives the most votes in the electoral college becomes president of the US, and this declaration is instantiated during the swearing in, but in order to understand how and why these standing declarations are present we need to understand the 'background ideology' of democracy that has been accepted by a group. The acceptance of a particular belief system by a social group is itself a social fact, as it depends upon some form of collective intentionality. We should then expect a certain kind of dependence relation between particular social facts, as some instances of the application of a declaration depend on pre-existing group beliefs. This is the type of analysis that Gramsci's account suggests, and it opens up the possibility of providing a critique of the ideological foundations of social entities. 
Gramsci's approach also offers us new potential for understanding the nature of collective acceptance. While, as we saw, Searle allows for various degrees of acceptance, he does not provide reasons for this differentiation. A framework for explicating these degrees is built into Gramsci's account. The stronger the pull of the hegemonic ideology, the more robust the collective acceptance will be in specific cases. Further, in hierarchical societies the levels of acceptance of specific subgroups may be tied to the relevance of the accepted belief system for those groups. The hegemonic subgroups in society may then be seen as the 'operative members' of the larger social group and display enthusiastic endorsement of a social entity, while the less powerful groups are left to simply 'go along with it'. ${ }^{11}$

The final area of broad agreement between Searle and Gramsci on the metaphysical question is the importance of functions. Both argue that social entities are defined by their functions. Here as well, Gramsci's view can benefit from a specification of functions in terms of status function, rather than simply agentive functions. This is necessary because Gramsci employs the term function in several ways, and generally means it in the sense of function for the ruling social groups. By incorporating this distinction, and clarifying the difference between this general sense of function, and the specific sense of status functions in terms of deontic powers, ${ }^{12}$ we can more precisely delineate the different types of social entities. Gramsci, on the other hand, suggests a method for the normative evaluation of functions. His discussion of the 'rationality' of functions involves the study of the history of a social object. He argues that we should take the 'genealogical perspective' in order to investigate the origins of a social object, the purpose it was meant to serve, and its appropriateness in our current context. In this way then, we can determine whether we should continue to collectively accept that object as a part of our social reality. The upshot of this point is that we cannot understand status functions simply in terms of the deontic powers that result from them; we must also investigate their genealogy.

\subsection{Epistemological question}

With respect to the epistemological question, we also see substantial agreement, as they both hold that while social entities are metaphysically subjective, they are also epistemically objective. Thus both defend the objectivity of the domain of the social sciences. This is not surprising as Searle states that his work will deepen our understanding of social phenomena generally and help our research in the social sciences' (2010, p. 5) and Gramsci takes himself to be carving out the domain of a particular social science, namely HM.

The differences are best brought out by discussing a problem case for Searle. As Thomasson (2003), and several others (Tuomela, 2003, 2013, Hindriks, 2011) have pointed out, Searle does not discuss cases of derivative or unintended social phenomena, such as recessions, in his earlier work. The important point about such cases is that they seem to represent social or institutional facts that do not require collective acceptance or recognition. They simply arise from other institutional facts that have been accepted, such as money, markets, and contracts. Because Searle argues that institutional facts necessarily come with their own deontology, and thereby offers a restricted view of institutional facts, he denies that these are institutional facts $(2010$, pp. 23, 116-119). These types of phenomena are often the subject of social-scientific inquiry, and so Searle is forced to admit that his account 
only applies to the 'ground-floor' institutional facts that carry deontological implications.

Gramsci, however, is faced with the opposite problem. Because he argues that all objects that enter into the social relations become objects of HM, he may be charged with failing to differentiate between genuine institutional objects which rely on intentionality and those that simply arise as a result of the 'ground-floor' institutional objects. Here Gramsci's account could benefit by more precisely determining the bounds of 'primary social entities', such as corporations, laws, and contracts, and 'secondary social entities', which are social in a derived sense, such as statistical hiring and firing regularities. ${ }^{13}$

The novelty of Gramsci's account on this issue again comes from his focus on the historical nature of social objects, and the necessity of taking the 'genealogical perspective' in order to conduct adequate analysis of them. One of the reasons that we can discover new things about social objects for Gramsci is that they depend on a historical development that may be initially opaque to us. We are normally confronted with a pre-existing social object, rather than the direct constructors of it. Gramsci's emphasis on this point highlights that we need to explore the prima facie unknown historical dimensions of social phenomena. This emphasis is seen, for example, in Gramsci's claim about the 'rationality' of the functions of social objects, and it is pervasive in his account. One of the important connections here is that it may often be the case that the 'secondary social phenomena' fall out of 'irrational' social objects. Thus, unwanted and unintended social regularities, such as recessions, may stem from social objects whose functions are no longer rational given current social practices and attitudes. We can therefore discover new facts about the functions of primary social entities by researching their history, and we can connect these analyses to the unintended consequences that derive from the current acceptance of primary entities.

\subsection{Power and coercion in social reality}

Both Gramsci and Searle argue that social reality is intimately connected to power relations in a society, and attempt to provide some autonomy to social reality in order to explain how we can experience our own intentional creations as foreign and coercive. We experience social entities as coercive because they are fleshed out in terms of what specific people are capable of doing in specific situations. The police officer can pull the driver over because of the status attached to his position, and for the driver this institutional fact may appear to be coercive.

It is with respect to the second part of the question of power, which concerns the coercion that results from the unequal abilities of different social groups to create social objects, that we see the benefits of a Gramscian analysis of social reality. To see how these benefits arise, we may introduce a distinction developed by Epstein (2014) between the 'grounds' and 'anchors' of social objects. Epstein begins by considering a single institutional fact, $\mathrm{F}$, and then asking, in virtue of what is $\mathrm{F}$ the case? He then distinguishes between two kinds of explanations. In his earlier discussion of money (1995, p. 28), Searle states that the constitutive rule is:

(1) Bills issued by the Bureau of Engraving and Printing count as dollars in the US. 
The first answer to our question is then present in the antecedent phrase. The bill I am holding is a US dollar because it was issued by the Bureau of Engraving and Printing. Epstein calls these types of explanations the 'grounds' of institutional facts $(2014$, p. 76). But this explanation is incomplete. We must also ask, in virtue of what is (1) the case? The answer to this is a fact of the following form:

\section{(2) People in the US collectively accept (1)}

Epstein then labels facts expressed by (2) the 'anchors' of S (2014, p. 81). The basic idea is that there is a difference between (1) and (2), namely that (1) has the job of giving the conditions an object must satisfy in order to be a dollar, while (2) has the job of giving the facts that put those satisfaction conditions in place.

With this distinction in mind, we can clearly state the difference between Searle's and Gramsci's accounts of power. Searle takes power to arise from (1), which depends on (2), while Gramsci argues that the facts in virtue of which (2) is the case depend on pre-existing power relations. In other words, instead of making power relations dependent on the grounds of social entities, Gramsci argues that the 'anchors' of social reality are power dependent. This does not entail that Gramsci cannot accept that specific, explicit forms of power may arise from (1), such as the capacity to purchase goods and services, but it does add a dimension to his account of the coercive nature of social reality.

According to Gramsci, collective acceptance is a notion that is already imbued with distinct and implicit relations of power between social groups. He attempts to show that social entities depend upon belief systems, which in turn depend on facts about the hegemonic positions of certain social groups. Only hegemonic groups are able to 'historicize' their belief systems and put the background conditions required for the application of specific declarations in place. For many individuals then, the social reality they encounter appears coercive because it is based on belief systems that run counter to their own, but have been accepted on the basis of the relative positions of the group to which they belong. ${ }^{14}$ Thus, the creation of social objects is itself coercive.

Several aspects of this position need to be clarified in relation to the modifications to Gramsci's theory we have adopted. First, it may be argued that these power relations are themselves social facts, and are simply based on more fundamental applications of non-power-dependent grounds that have created specific institutions. While it is true that these pre-existing power relations are social facts, they are not necessarily institutional facts; social facts only require collective intentionality and therefore may arise in pre-institutional systems, while institutional facts demand status function declarations. For Gramsci, although the exercise of hegemonic power often takes place within institutional structures, as these function to 'historicize' the belief systems of the ruling social group, we may still hold that the formation and belief system of the group depend simply on social facts.

Searle discusses a very specific type of power which relies on explicit institutional authority. While it is certainly important to precisely capture this form of power, there are also much broader forms of power in society. There is no reason to limit our analysis of the creation of institutional reality to the power created by institutional reality instead of the forms of pre-institutional power that create it. Further, we may consistently argue that the primary social objects created by specific declarations are dependent on pre-existing power relations. This comports well with 
the idea that derivative social facts, such as recessions, also depend on more basic social facts about power relations and the acceptance of certain primary social objects, without themselves being institutional facts.

The second concern comes from Searle's conditions on 'any reasonable discussion of power'. On the surface, it appears that Gramsci's account of power violates both the 'intentional' condition and the 'exactness' condition. We may attempt to mitigate this by arguing that we can specify groups, rather than individuals, that exercise certain powers by getting other groups to adopt specific belief systems, and that they do so intentionally. Even if we loosen this to include Searle's notion of background power, however, this does not seem like a plausible line. Any further clarification of Gramsci's claim would need to allow for the cases in which the groups in question are loosely formed, and therefore not capable of acting intentionally, or of being specified exactly.

The more promising response is to reject Searle's conditions. While it may be useful to distinguish between explicit and direct exercises of power and more diffuse instances of 'structural power', there is no reason to restrict an analysis of power to the first kind. First, it is not clear that Searle himself succeeds in doing this. His claim that power can be exercised 'unconsciously' does not seem to be consistent with the intentionality condition (2010, p. 158). Even if we can always specify instances of background power, and therefore meet the exactness condition, it appears that unconscious exercises of power are not intentional acts. Second, as Hindriks argues, deontic powers may arise from unintentional acts. He asks us to imagine a 'president signing a document that she has not carefully read' and points out that 'It seems that deontic consequences follow irrespective of the fact that the act was unintentional with respect to them' (2011, p. 384). Finally, it is not clear that the idea of background power is useful as Searle construes it. He argues, for example, that because of background power, he 'cannot give a lecture wearing a dress and high heels', and this restriction results from the sanctions that would be imposed upon him and his reluctance to accept those sanctions. If we ignore the fact that some male-born professors can and do give lectures in high heels and dresses, this analysis has a further problem. It simply accepts that these norms are in place, and fails to recognize both that social norms are often uncodified, implicit, and function below the level of linguistic and mental representation, and that the acceptance of these norms is based on a certain set of implicit power relations between groups of people. To ignore this issue is to fail to give an adequate account of power in society.

\section{Conclusion}

Gramsci's account of social reality benefits greatly from its place within his account of political power, civil society, and hegemony. By incorporating these ideas into his view of the creation of social objects, Gramsci is able to develop a nuanced view of social reality that goes beyond the analysis provided by Searle with respect to the relation between social reality and power. At the same time, Gramsci shares with some modern accounts the idea that the material composition of social entities does not fully capture all there is to be explained about them, which leads him to the view that certain kinds of objects have properties on the basis of the collective acceptance of those properties by social groups. This in turn leads him to address three central issues of social ontology: ontological creativity, epistemic opacity and 
coercion. On these issues, Gramsci's account suffers from underspecification at the level of the individual agent and the particular social object. We can rectify each of these faults by combining the tools developed by modern theorists, such as declarations, status functions, groups with operative and non-operative members, 'grounds' and 'anchors', and deontic power with Gramsci's analysis of hegemony and political power.

Gramsci's specific contribution is his recognition that social power does not simply arise from social reality, but goes into creating it. His account of hegemony and civil society provides the framework with which we can analyze the difference between the institutional power described by Searle and the wider sense of social power upon which the generation of social reality relies. Gramsci insists that we need to provide an 'ideological critique'15 of the background belief system that informs the nature of the collective acceptance of a specific social object, and that we need the 'genealogical perspective' towards a social object in order to understand its larger function and place in society. These elements represent a novel addition to the modern debate and extend the analysis of social power to the differential ability of societal subgroups to construct the social world, which, in turn, allows us to develop a more complete and powerful theory of social reality.

\section{Disclosure statement}

No potential conflict of interest was reported by the author.

\section{Notes}

1. This account of the aims of social ontology is greatly informed by the work of Thomasson $(2003,2009)$, as well as Searle $(1995,2010)$, Tuomela $(2003,2013)$, and Frank Hindriks (2011). Given the connections aimed at in this paper, it should also be noted that the term 'social ontology' was brought into the modern lexicon in the context of an analysis of Marxist thought by Gould (1978).

2. This section embraces an interpretation developed by Alessandro Salice in a seminar on Gramsci at the University of Vienna in 2012 and sketched in Salice (2009).

3. The title of Bukharin's original text in English is Historical Materialism: A System of Sociology. Gramsci, however, refers to it as 'Il Saggio Populare' ('The Popular Manual'). I follow him in that usage. For further discussion of this issue see J.A. Buttigeig, 'Notes' in A. Gramsci (1991, p. 520).

4. The second part of the reference is to the original section in Gramsci's notebooks.

5. For further discussion of this point see Fontana (2012).

6. The following distinctions are worked out by Searle (2010, p. 18).

7. For a discussion of the difficulty of defining 'historical' in Gramsci, and the relation of 'historical' to 'social', 'conventional', and 'artificial', especially with respect to the relation between 'social object' and 'historical object', see Salice (2009).

8. Gramsci's use of consent here is idiosyncratic. It is meant as a description of the psychological state of the subjects of rule, denoting some kind of acceptance. It is not meant to carry with it the normative connotations that it traditionally does, say, for example, in social contract theory (Femia, 1981, p. 37-43).

9. There is some tension between those who wish to analyze social reality in terms of social objects and those who wish to analyze social reality in terms of social facts (Thomasson, 2003, 2009, Epstein, 2014, Searle, 2014). It appears that Gramsci, who discusses social objects, and Searle, who discusses social facts, may be in disagreement on this issue. However, as Gramsci is not working with the same distinctions, language or conceptual background we can remain neutral on the issue here. 
10. We of course do not have to accept some of Searle's more controversial claims about the primacy of language in social reality. For a critique of these claims see Hindriks (2011).

11. An account of hierarchical groups is given by Tuomela (2013).

12. This is not to suggest that a Gramscian analysis should take on board the contentious claim that all status functions necessarily come with deontic powers (Tuomela, 2013, p. 240).

13. For a detailed account along these lines see Tuomela (2013, p. 223).

14. This picture is somewhat simplified for the sake of analysis. Belief systems are not formed and do not exist in isolation; they are often constituted relationally and depend on more than simple group membership. Nonetheless, simplifying from these complications gives us a clearer idea of how this process functions in general.

15. The question of how to engage in this type of critique has not been dealt with in this paper. Nonetheless, further exploration of Gramsci may prove useful in developing such a method, as much of his work concerns practical issues of this nature, rather than the more theoretical issues dealt with here. This can be seen in Gramsci's influence on cultural studies.

\section{Notes on contributor}

Matthew Rachar is a graduate student in the Department of Philosophy at the Graduate Center, CUNY. He is interested in social ontology, collective intentionality, philosophy of social science, and Marxist political philosophy.

\section{References}

Bukharin, N., 1969. Historical materialism: a system of sociology. Ann Arbor: University of Michigan Press.

Epstein, B., 2014. The ant trap: rebuilding the foundations of the social sciences. Oxford: Oxford University Press.

Femia, J., 1981. Gramsci's political thought. Oxford: Oxford University Press.

Fontana, B., 2006. State and society: the concept of hegemony in Gramsci. In: M. Haugaard and H. Lentner, eds. Hegemony and power: consensus and coercion in contemporary politics. New York: Lexington Books, 23-44.

Fontana, B., 2012. The concept of nature in Gramsci. In: M. Ekers, et al., eds. Gramsci: space, nature, politics. Oxford: Wiley-Blackwell, 123-141.

Gould, C., 1978. Marx's social ontology: individuality and community in Marx's theory of social reality. Cambridge, MA: MIT Press.

Gramsci, A., 1971. Selections from the prison notebooks. Q. Hoare and G. Nowell-Smith, eds., trans. New York: International Publishers.

Gramsci, A., 1996. Prison notebooks vol. 2. J. Buttigieg, eds., trans. New York: Columbia University Press.

Gramsci, A., 2007. Prison notebooks vol. 3. J. Buttigieg, eds., trans. New York: Columbia University Press.

Gramsci, A., 2012. Selections from cultural writings. D. Forgas and G. Nowell-Smith, eds., William Boelhower, trans. Chicago, IL: Haymarket Books.

Hindriks, F., 2011. Restructuring Searle's making the social world. Philosophy of the Social Sciences, 43 (3), 373-389.

Russell, B., 1967. Problems of philosophy. Oxford: Oxford University Press.

Salamini, L., 1981. The sociology of political praxis: an introduction to Gramsci's theory. London: Routlege and Kegan Paul.

Salice, A., 2009. History and objects: Antonio Gramsci and social ontology. In: V. Munz, K. Puhl, and J. Wang, eds. Language and world: proceedings of the 32nd international Wittgenstein symposium. Kirchberg/Wechsel: Austrian Ludwig Wittgenstein Society, 367-369.

Searle, J., 1995. The construction of social reality. New York: Free Press.

Searle, J., 2010. Making the social world. New York: Oxford University Press. 
Searle, J., 2014. Are there social objects. In: M. Gallotti and J. Michael, eds. Perspectives on social ontology and social cognition, Studies in the philosophy of sociality, Dordrecht: Springer, 17-26.

Thomasson, A., 2003. Foundations for a social ontology. Protosociology, 18-19, 269-290.

Thomasson, A., 2009. Social entities. In: R. Le Poidevin, et al., eds. Routledge companion to metaphysics. London: Routledge, 545-554.

Tuomela, R., 2003. Collective acceptance, social institutions, and social reality. American Journal of Economics and Sociology, 62, 123-165.

Tuomela, R., 2013. Social ontology. Oxford: Oxford University Press. 